\title{
IMPLEMENTASI PENDIDIKAN KARAKTER DI SEKOLAH DASAR
}

\author{
${ }^{1)}$ Nurratri Kurnia Sari; ${ }^{2)}$ Linda Dian Puspita \\ ${ }^{1)}$ PGSD Univet Bantara Sukoharjo \\ E-mail: nuurratrikurniasari@gmail.com \\ ${ }^{2)}$ PGSD Univet Bantara Sukoharjo \\ E-mail: nuurratrikurniasari@gmail.com
}

\begin{abstract}
Abstrak
Penelitian ini bertujuan untuk mendiskripsikan pelaksanaan pendidikan karakter di SD Negeri Joho 02 Sukoharjo dan hambatan yang dihadapi guru dalam melaksanakan pendidikan karakter di SD Negeri Joho 02 Sukoharjo. Penelitian ini merupakan penelitian deskriptif kualitatif. Teknik pengumpulan data yang digunakan adalah observasi, wawancara dan dokumentasi. Instrumen utama adalah peneliti dengan menggunakan alat bantu pedoman wawancara dan pedoman observasi. Prosedur analisis dalam penelitian ini adalah: Reduksi data, penyajian data, dan verifikasi/penarikan kesimpulan. Hasil penelitian ini menunjukkan bahwa bentuk pelaksanaan pendidikan karakter di SD Negeri Joho 02 Sukoharjo terwujud dalam integrasi dalam program pengembangan diri, integrasi dalam kegiatan pembelajaran, serta nilai karakter yang dikembangkan sekolah. Integrasi dalam program pengembangan diri terdiri atas: Kegiatan Rutin, keteladanan, kegiatan spontan, dan pengkondisian. Integrasi dalam kegiatan pembelajaran terwujud dalam pencantuman nilai karakter di dalam RPP dan Silabus yang diimplementasikan dalam kegiatan pembelajaran. Nilai karakter yang dikembangkan di SD Negeri Joho 02 Sukoharjo yaitu nilai religius, jujur, disiplin, bersahabat/komunikatif, tanggung jawab, dan toleransi. Hambatan Pelaksanaan Pendidikan Karakter Di SD Negeri Joho 02 Sukoharjo antara lain: Beberapa siswa yang bersikap manja, pengaruh teman dan lingkungan yang tidak baik terhadap perilaku siswa, beberapa siswa yang agak terlambat belajar sehingga memerlukan waktu yang lama untuk menanamkan nilai keberanian, disiplin dan tanggung jawab, serta guru belum dapat memilih nilai karakter yang sesuai dengan mata pelajaran dan terkadang belum dapat menjadi teladan atas nilai karakter yang dipilih.
\end{abstract}

\section{Kata Kunci : Pendidikan Karakter, Sekolah Dasar}

\begin{abstract}
This study aims to improve the learning outcomes of the matematics material Two Variable Linear Equal learning model type Think pair share in students of class VIII H SMP Negeri 5 Sukoharjo first semester academic year 2017/ 2018. This research is a Classroom Action Research conducted in class VIII H SMP Negeri 5 Sukoharjo first semester of academic year 2017/ 2018 with 32 students. Data collection techniques used are tests, observations, and documentation. The stages of data analysis in this study are data collection, data reduction, data presentation, and conclusion. The success indicator is the average score of the student's test at least 80,0 and many students with a value above the minimum mastery criteria $(\mathrm{KKM})$ of 70,0 reach $\geq 93 \%$.Based on the research that has been done, it can be concluded that the application of cooperative learning model type Think pair share can improve learning result of matematics material of Two Variable
\end{abstract}


Linear Equal letters student of class VIII H SMP Negeri 5 Sukoharjo . Before the action / pre cycle, student learning outcomes reaching KKM 19 students or $59,37 \%$, in cycle I, 23 students or $71,87 \%$ and in cycle II, 30 students or $93,75 \%$. The average value of the class before the action/ pre cycle was $71,87 \%$ after the first cycle action was 72,0 and after the second cycle action was 81,87

Keyword: Think pair share model, learning result mathematics

\section{PENDAHULUAN}

Pendidikan merupakan salah satu faktor penting dalam kehidupan manusia. Berdasarkan Undang-Undang No. 20 Tahun 2003 tentang Sistem Pendidikan Nasional menyebutkan bahwa "Pendidikan merupakan usaha sadar dan terencana untuk mewujudkan suasana belajar dan proses pembelajaran, agar peserta didik secara aktif mengembangkan potensi dirinya untuk memiliki kekuatan spiritual keagamaan, pengendalian dirinya, masyarakat, bangsa dan negara".

Undang-Undang Sisdiknas Nomor 20 Tahun 2003 pasal 3 menyatakan bahwa Pendidikan Nasional berfungsi mengembangkan kemampuan dan membentuk watak serta peradaban bangsa yang bermartabat dalam rangka mencerdaskan kehidupan bangsa. Tujuan Pendidikan Nasional untuk mengembangkan potensi peserta didik agar menjadi manusia yang beriman dan bertakwa kepada Tuhan Yang Maha Esa, berakhlak mulia, sehat, berilmu, cakap, kreatif, mandiri, dan menjadi warga negara yang demokratis serta bertanggung jawab.

Tumbuh kembangnya suatu bangsa erat kaitannya dengan masalah pendidikan. Apabila Sumber Daya Manusia (SDM) yang dimiliki berkualitas, maka dapat menghasilkan output yang baik dalam menunjang kemajuan bangsa. Namun pada kenyataannya, peningkatan sumber daya manusia terutama dalam bidang pendidikan masih mengalami banyak hambatan. Salah satunya yaitu melalui pendidikan karakter yang dilaksanakan oleh sekolah.

Karakter merupakan cara berpikir dan berperilaku yang menjadi ciri khas tiap individu untuk hidup dan bekerjasama, baik dalam lingkup keluarga, masyarakat, bangsa dan negara. Karakter juga dapat disbut kumpulan nilai yang 
melandasi pemikiran, sikap dalam perilaku yang dilakukan. Individu yang berkarakter adalah individu yang bisa membuat keputusan dan siap mempertanggungjawabkan tiap akibat dari keputusan yang ia buat. (Subur, 2015; Fatchul Muin, 2016)

Pendidikan yang mengembangkan nilai-nilai karakter pada peserta didik sehingga mereka memiliki nilai dan karakter sebagai karakter dirinya, menerapkan nilai-nilai tersebut dalam kehidupan dirinya, sebagai anggota masyarakat dan warga negara yang religius, nasionalis, produktif, dan kreatif. Pendidikan karakter merupakan suatu proses dan upaya untuk menanamkan dan mengembangkan nilai-nilai karakter pada diri peserta didik sehingga mereka dapat melaksanakan nilai-nilai tersebut terhadap Tuhan Yang Maha Esa, diri sendiri, sesama serta bangsa dan negara. Melalui pendidikan karakter diharapkan dapat peserta didik menerapkan nilai karakter tentang pemahaman akan tertapi tertanam nilai-nilai keperdulian terhadap Tuhan Yang Maha Esa, diri sendiri, sesama, lingkungan, maupun masyarakat dan bangsa secara keseluruhan sehingga menjadi manusia sempurna sesuai dengan kodratnya. (Muhammad Fadlillah dan Lilif Mualifatu Khorida, 2014).

Sekolah dituntut untuk mampu membentuk karakter siswa melalui kegiatan pembelajaran di kelas maupun di luar kelas, serta memiliki program yang mampu membentuk karakter peserta didik di sekolah. Peran sekolah sebagai tempat pembentukan karakter siswa dirasa penting dan memiliki pengaruh yang cukup besar. Guru dituntut untuk dapat terus mengembangkan diri dan mampu menjadi teladan bagi siswa untuk membentuk karakter yang baik. Pendidikan karakter merupakan salah satu aspek penting di dalam proses pendidikan yang diterima peserta didik.

Pendidikan karakter dapat diterapkan mulai pendidikan keluarga maupun sukolah. Pendidikan keluarga maupun pendidikan dalam sekolah, orang tua, dan guru tetap sadar bahwa pembangunan tabiat yang agung adalah tugas mereka. pendidikan karakter seharusnya membawa peserta didik ke pengenalan nilai secara kognitif, pengahayatan nilai secara afektif dan akhirnya ke pengalaman nilai secara nyata. Permasalahan pendidikan karakter yang selama ini ada, di 
sekolah misalnya, perlu segera dikaji dan dicari alternatif-alternatif solusinya serta perlu dikembangkan secara lebih operasional sehingga mudah diimplementasikan. (Syamsul Kurniawan, 2016:)

Berdasarkan observasi awal, pembelajaran di SD Negeri Joho 02 Sukoharjo masih lebih banyak menekankan pada aspek kognitif (pengetahuan) dibandingkan dengan aspek afektif (sikap). Ditambah, guru masih mengalami kesulitan dalam mengintegrasikan nilai-nilai karakter di dalam pembelajaran, meskipun nilai-nilai karakter yang diharapkan dalam pembelajaran telah dicantumkan dalam Rencana Pelaksanaan Pembelajarana (RPP). Selain itu, masih terdapat siswa yang belum melaksanakan nilai-nilai karakter yang ditanamkan oleh sekolah. Selain itu, masih kurangnya kegiatan yang diprogramkan sekolah yang ditujukan untuk membentuk karakter pada siswanya. Diantaranya yaitu belum adanya kegiatan ekstrakurikuler. Kegiatan ekstrakurikuler tesebut yaitu ekstrakurikuler pramuka dan ekstrakurikuler komputer yang berhenti dilaksanakan oleh sekolah.

Sekolah diharapkan mampu membentuk siswa menjadi pribadi yang berkarakter dan berkepribadian baik sesuai dengan nilai dan norma yang dianut dalam masyarakat, khususnya pada siswa Sekolah Dasar Negeri Joho 02 Sukoharjo. Pentingnya upaya dilakukan pendidikan karakter maka dapat dirumuskan masalah pada penelitian ini adalah 1)Bagaimana bentuk pelaksanaan pendidikan karakter di SD Negeri Joho 02 Sukoharjo? 2)Hambatan apa yang dihadapi oleh guru dalam melaksanakan pendidikan karakter di SD Negeri Joho 02 Sukoharjo?

\section{METODE PENELITIAN}

Penelitian ini menggunakan pendekatan penelitian kualitatif karena menyajikan data dalam bentuk kata-kata. Jenis penelitian yang digunakan oleh peneliti adalah penelitian deskriptif. Hal ini peneliti ingin mengetahui implementasi dan hambatan yang dilakukan di sekolah dasar. Tempat pelaksanaan dalam penelitian ini adalah SD Negeri Joho 02, waktu penelitian 5 bulan yaitu dari bulan maret sampai juli 2018. 
Teknik pengumpulan data pada penelitian ini, melalui observasi, wawancara dan dokumentasi. Pada metode observasi digunakan untuk mengetahui kegiatan-kegiatan sekolah yang berkaitan dengan pembentukan karakter siswa, baik itu dalam kegiatan pembelajaran maupun kegiatan non pembelajaran. Pada wawancara digunakan untuk memperoleh informasi dari sumber secara lebih mendalam yang tidak bisa ditemukan melalui observasi yang berasal dari kepala sekolah, guru dan siswa. mengumpulkan data dalam bentuk dokumen-dokumen, yang diantaranya berupa Silabus, Rencana Pelaksanaan Pembelajaran (RPP), dan foto-foto yang dapat dijadikan sumber data.

Data yang telah diperoleh oleh peneliti selama di lapangan perlu diuji keabsahannya. Uji keabsahan data dalam penelitian kualitatif meliputi uji credibility (validitas internal), transferability (validitas eksternal), dependability (reliabilitas), dan confirmability(obyektifitas). Pada penelitian ini peneliti memfokuskan uji kebasahan data melalui triangulasi. Pengumpulan data dengan triangulasi, maka sebenarnya peneliti mengumpulkan data yang sekaligus menguji kredibilitas data, yaitu mengecek kredibilitas data dengan berbagai teknik pengumpulan data dan berbagai sumber data (Sugiyono 2014:330).

Pada penelitian ini, peneliti menggunakan triangulasi sumber. Sumber penelitian ini terdiri dari sumber data primer dan sekunder. Sumber data primer yaitu observasi dan wawancara, sedangkan sumber data sekunder yaitu dokumentasi. Peneliti menggunakan observasi partisipatif, wawancara, dan dokumentasi.

Kerangka berfikir penelitian ini dapat disajikan pada gambar berikut 


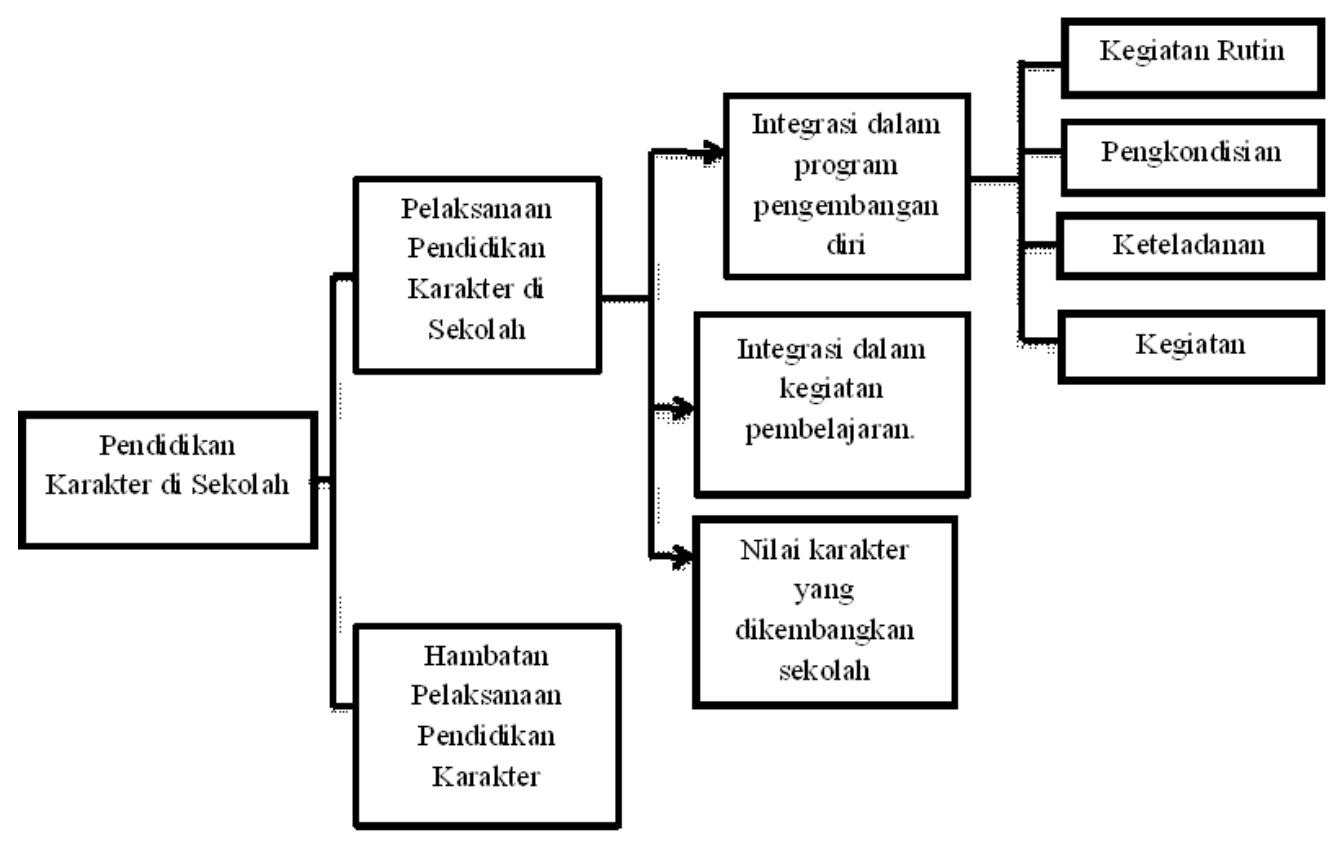

Gambar 1. Kerangka berpikir

\section{HASIL PENELITIAN DAN PEMBAHASAN}

\section{a. Implemtasi Pendidikan Karakter}

1) Bentuk Pelaksanaan Pendidikan Karakter

Bentuk pelaksanaan pendidikan karakter di SD Negeri Joho 02 diwujudkan melalui integrasi dalam program pengembangan diri, integrasi dalam kegiatan pembelajaran serta nilai karakter yang dikembangkan sekolah. Berikut deskripsi tentang integrasi dalam program pengembangan diri dan integrasi dalam kegiatan pembelajaran serta nilai karakter yang dikembangkan sekolah. Intergrasi pada pendidikan karakter pada penelitian ini adalah melalui pengembangan diri dan pembelajaran. Pada pengembangan diri meliputi

a) Kegiatan Rutin

Kegiatan rutin merupakan kegiatan yang secara rutin dilakukan oleh sekolah untuk menanamkan karakter kepada siswa. Berdasarkan hasil wawancara pada hari Rabu, 26 April 2017 terkait kegiatan rutin yang dilakukan sekolah, kepala sekolah menyatakan "upacara, sholat dhuha dan sholat dhuhur, disiapkan dan berdoa". Hal tersebut didukung dengan pernyataan guru terkait kegiatan rutin yang dilaksanakan oleh sekolah dalam 
rangka menanamkan karakter kepada siswa yaitu upacara hari senin dan hari besar lainnya, berdoa sebelum dan sesudah pelajaran, sholat berjamaah, serta piket bersama.

Berdasarkan hasil wawancara dengan kepala sekolah dan guru, dapat disimpulkan bahwa kegiatan rutin yang dilaksanakan oleh sekolah dalam rangka menanamkan karakter kepada siswa antara lain pada keigiatan upacara yang dilakukan setiap hari senin. Kegiatan upacara dilaksanakan wajib bagi siswa. Selanjutnya kegiatan piket, kegiatan piket yang dilakukan secara terjadwal pada setiap kelas. Pendidikan karakter juga dilakukan pada kegiatan spotan yang diwujudkan melalui menjenguk teman sakit, takziah dan lain-lain. Selain itu, kegiatan pengkondisian dilaksanakan melalui penertiban di kelas, pemberian motivasi belajar dan lain-lain.

b) Keteladanan

Maksud kegiatan keteladanan disini adalah suatu kegiatan yang dilakukan oleh pengawas, kepala sekolah, dan staf administrasi di sekolah yang dapat dijadikan sebagai model bagi siswa. Dalam hal ini guru beperan langsung sebagai contoh bagi siswa. Berdasarkan hasil wawancara peneliti dengan kepala sekolah pada 26 April 2017 terkait kegiatan keteladanan, kepala sekolah menyatakan "Berpakaian rapi, bertutur kata yang sopan, sholat dhudhur di sekolah, datang tidak terlambat, dan lain sebagainya". Hal tersebut sesuai dengan pernyataan guru, bahwa keteladanan yang diberikan kepada siswa berupa berbicara sopan, berpakaian rapi, disiplin serta bertegur sapa. Dapat disimpulkan beberapa teladan yang diberikan guru dan kepala sekolah kepada siswa diantaranya berpakaian rapi, berbicara sopan, datang tepat waktu, disiplin, sholat berjamaah dan saling mengucap salam.

Berdasarkan hasil observasi peneliti, semua guru sudah berusaha memberikan teladan yang baik kepada peserta didik. Selama pengamatan, peneliti selalu menemui bahwa kepala sekolah dan guru selalu berpakaian rapi dan sopan, guru dan kepala sekolah selalu menggunakan pakaian yang sesuai seragam hari tersebut. Peneliti juga menemui bahwa kepala sekolah dan guru selalu menggunakan bahasa yang sopan ketika berbicara kepada sesama guru 
maupun kepada siswa, hal tersebut terlihat pada saat kepala sekolah dan guru menggunakan bahasa krama inggil ketika berbicara dengan sesama guru ataupun kepala sekolah. Hal tersebut juga terlihat pada saat peneliti melakukan observasi pembelajaran pada kelas I sampai V, guru menggunakan bahasa yang sopan ketika menyampaikan pelajaran, serta menggunakan pakaian yang rapi dan sopan. Namun beberapa kali peneliti juga menemui bahwa guru masih menggunakan bahasa ngoko lugu kepada siswa pada saat menegur siswa yang ramai.

Untuk kegiatan sholat berjamaah, pada pengamatan peneliti di sekolah, guru belum ada yang mengikuti kegiatan sholat berjamaah di masjid, hanya guru agama Islam saja yang ikut kegiatan sholat berjamaah bersama siswa. Untuk kedisiplinan, pada saat observasi peneliti sudah menemui bahwa guru dan kepala sekolah sudah berusaha untuk datang tepat waktu ke sekolah, namun peneliti juga masih menemui ada guru yang datang terlambat masuk kelas pada jam pertama. Peneliti juga menemui beberapa guru juga terlambat masuk ke kelas untuk kegiatan pembelajaran setelah jam istirahat. Pada kegiatan upacara, peneliti juga menemui masih ada 2 orang guru yang datang terlambat.

2) Integrasi dalam Kegiatan Pembelajaran

Pelaksanaan pendidikan karakter di sekolah juga diintegrasikan dalam Kegiatan Pembelajaran di kelas. SD Negeri Joho 02 Sukoharjo dalam pembelajarannya masih menggunakan Kurikulum Tingkat Satuan Pendidikan. Integrasi pendidikan karakter dilaksanakan melalui penanaman nilai-nilai karakter di dalam pembelajaran. Dalam pembelajaran, sebelumnya guru sudah membuat RPP sebelum pembelajaran sebagai pedoman guru dalam mengajar. Nilai-nilai karakter yang akan ditanamkan di dalam pembelajaran disisipkan di dalam RPP dan didasarkan pada Silabus yang ada. Terkait pencantuman nilai karakter dalam RPP dan silabus, pada wawancara tanggal 26 April 2017 kepala sekolah menyatakan"Iya, dicantumkan sesuai dengan KD-nya". Pernyataan kepala sekolah tersebut sesuai dengan pernytaan guru bahwa nilai karakter dicantumkan dalam RPP dan silabus. Hasil wawancara tersebut juga 
didukung dengan dokumen silabus dan RPP kelas I sampai V yang diperoleh peneliti, dimana di dalam RPP dan silabus sudah ada nilai-nilai karakter yang akan dikembangkan sesuai dengan mata pelajarannya.

Terkait dengan dengan bagaimana cara guru menanamkan nilai karakter pada siswa di dalam kegiatan pembelajaran, kepala sekolah menyatakan "Diimplementasikan pada KD sesuai dengan mata pelajarannya, guru memberikan contoh tindakan nyata, kedisiplinan melalui guru yang datang tepat waktu". Hal tersebut sesuai dengan pernyataan guru bahwa nilainilai karakter akan ditanamkan diimplementasikan melalui kegiatan dalam pembelajaran.

Pada perencanaannya, nilai karakter yang akan disampaikan pada kegiatan pembelajaran dimasukkan pada Rencana Pelaksanaan Pembelajaran. Pada pelaksanaannya, nilai religius ditanamkan melalui kegiatan sholat berjamaah pada jam istirahat serta berdo bersama sebelum dan sesudah jam pelajaran. Nilai disiplin ditanamkan melalui pemberian PR yang tampak pada pembelajaran kelas I ( 9 Mei 2017), pembelajaran kelas II ( 26 April 2017), pembelajaran kelas III ( 27 April 2017), pembelajaran kelas IV (10 Mei 2017) dan pembelajaran kelas V ( Kamis, 11 Mei 2017) serta masuk kelas tepat waktu dan pulang tepat waktu sesuai dengan jadwal. Nilai mandiri ditanamkan melalui pemberian tugas secara individu, hal tersebut tampak pada pembelajaran kelas II sampai V. Nilai tanggung jawab ditanamkan melalui pemberian tugas individu maupun kelompok. Nilai demokratis ditanamkan guru melalui pemberian tugas secara kelompok yang tampak pada pembelajaran kelas I pada Selasa, 9 Mei 2017. Akan tetapi dalam pelaksanaannya, guru belum mengimplementasikan nilai-nilai karakter tersebut di dalam kegiatan pembelajaran secara optimal. Pada pelaksanaannya guru masih banyak menekankan pada aspek kognitif. Akan tetapi guru sudah tampak berupaya untuk mengimplementasikan nilai-nilai karakter yang ada ke dalam pembelajaran.

Berikut hasil observasi peneliti dalam kegiatan pembelajaran pada kelas I sampai V. Kegiatan pembukaan, diawali dengan mengucapkan salam 
selamat pagi. Dilanjutkan dengan kegiatan apersepsi, yaitu guru mengucapkan salam semangat dan dilanjutkan pada mengulas kembali tentang pengertian tata tertib yang telah disampaikan pada pertemuan sebelumnya. Guru memberikan pertanyaan kepada siswa tentang pengertian tata tertib dan dimana saja tata tertib itu ada. Beberapa siswa pun menjawab pertanyaan tersebut. Kepada siswa yang menjawab pertanyaan guru meberikan pujian berupa kata-kata "iya, hebat" dan "iya, bagus". Selain itu guru juga membenarkan siswa yang masih belum menjawab pertanyaan dengan benar. Untuk kegiatan inti, guru memberikan pertanyaan tentang apa saja tata tertib yang ada di rumah dan di sekolah. Pada beberapa kesempatan, guru juga menegur siswa yang ramai, untuk mengatasi siswa yang kurang berkonsentrasi, guru mengajak siswa untuk bertepuk tangan dan menyanyikan lagu aku anak sehat. Untuk tugas, guru membagi siswa secara berkelompok dengan anggota 5-6 siswa. Siswa diberikan tugas tertulis untuk menyebutkan 5 peraturan di rumah dan 5 peraturan di sekolah. Setiap kelompok yang selesai diminta membacakan hasil di depan kelas.

3) Nilai-nilai Karakter yang dikembangkan

Pada dasarnya ada 18 nilai karakter yang perlu dikembangkan bagi peserta didik di sekolah, akan tetapi setiap sekolah memiliki beberapa karakter yang akan secara khusus dipilih untuk dikembangkan di dalam sekolah masing-masing. Berikut hasil wawancara yang peneliti lakukan dengan kepala sekolah terkait nilai karakter yang dikembangkan di SD Negeri Joho 02 Sukoharjo pada 26 April 2017, kepala sekolah menyatakan "Untuk nilai karakter yang secara khusus dikembangkan di SD Joho 02 ada nilai ketaqwaan atau kerohanian yaitu melalui kegiatan sholat berjamaah dan berdoa, kejujuran melalui koperasi kejujuran, kedisiplinan melalui upacara dan tutup gerbang setiap jam 07.00, tanggung jawab melalui kegiatan piket, dan toleransi melalui menjenguk dan melayat. Semua karakter juga dikembangkan disini tapi untuk yang paling ditekankan adalah nilai-nilai itu.”. 
Berdasarkan hasil wawancara tersebut peneliti dapat menyimpulkan beberapa karakter yang secara khusus diutamakan untuk dikembangkan di SD Negeri Joho 02 Sukoharjo.

Penanaman nilai religius tampak diwujudkan dalam kegiatan rutin sholat berjamaah bersama pada jam istirahat pertama dan kedua setiap hari. Dan diwujudkan pada kegiatan berdoa sebelum dan sesudah melaksanakan kegiatan pembelajaran.

Penanaman nilai kejujuran diwujudkan dalam pengadaan kantin kejujuran di sekolah. Setiap siswa yang membeli sesuatu akan membayar dan mengambil kembalian sendiri. Hal tersebut tampak pada observasi peneliti pada hari Selasa, 25 April 2017. Penanaman nilai kedisiplinan diwujudkan pada kegiatan upacara, masuk dan penutupan gerbang sekolah setiap pukul 07.00, istirahat sesuai waktunya dan masuk kelas tepat waktu setelah jam istirahat, serta pemberian tugas rumah kepada siswa.

Penanaman nilai bersahabat/komunikatif diwujudkan dengan kebiasaan siswa untuk bersalaman dengan guru ketika datang dan pulang sekolah. Untuk kegiatan bersalaman, selama peneliti melaksanakan observasi lebih dominan dilaksanakan oleh siswa kelas I, sedangkan untuk siswa kelas II sampai V peneliti belum menemui mereka bersalaman dengan bapak dan ibu guru di kantor. Nilai komunikatif ditanamkan melalui kegiatan pembelajaran, disaat siswa diberikan kesempatan untuk bertanya, menjawab dan menyampaikan pendapat. Penanaman nilai tanggung jawab diwujudkan dalam kegiatan piket, baik itu piket siswa maupun piket guru yang dilaksanakan setiap hari sesuai dengan jadwal yang telah dibentuk. Serta dalam bentuk pemberian tugas, baik itu PR, tugas individu, maupun tugas kelompok dan pemberian tugas kepada siswa dalam kegiatan upacara bendera. Penanaman nilai toleransi diwujudkan dalam kegiatan menjenguk dan melayat warga sekolah atau keluarga dari warga sekolah yang sedang mengalami kondisi sakit atau mengalami musibah. Serta ke dalam bentuk saling menghormati perbedaan agama. 


\section{b. Hambatan Pelaksanaan Pendidikan Karakter}

Dalam pelaksanaan pendidikan karakter yang dilaksanakan oleh sekolah, terdapat beberapa hambatan yang ditemui oleh guru dalam pelaksanaannya. Berdasarkan hasil wawancara dengan kepala sekolah pada 26 April 2017, kepala sekolah menyatakan "Terkadang ada siswa yang bersikap manja. Karena itu siswa diberikan pengertian dari hati ke hati, diberi tahu akibat dari perbuatannya di masa yang akan datang". hal tersebut juga ditambah dengan pernyataan $\mathrm{Wi}$ "Adanya pengaruh dari luar, dari temantemannya dan lingkungannya". Su menyatakan "Terkhusus pada anak yang agak lambat belajar agak sulit ditanamkan nilai keberanian, disiplin, dan tanggung jawab. Jadi pada mereka dibutuhkan waktu yang lebih lama". Dan Sus menyatakan"Guru belum dapat memilih nilai-nilai karakter yang sesuai dengan mata pelajaran yang diampunya, lalu guru juga terkadang belum bisa menjadi teladan atas nilai karakter yang dipilih". Berdasarkan wawancara, dapat disimpulkan bahwa hambatan yang dialami guru dalam melaksanakan pendidikan karakter kepada siswa diantaranya, ada siswa yang bersikap manja, pengaruh teman dan lingkungan terhadap perilaku siswa, terdapat beberapa siswa yang agak terlambat belajar sehingga memerlukan waktu yang lama untuk menanamkan nilai keberanian, disiplin dan tanggung jawab, serta guru belum dapat memilih nilai karakter yang sesuai dengan mata pelajaran dan terkadang belum dapat menjadi teladan atas nilai karakter yang dipilih.

Hasil wawancara tersebut didukung dengan hasil observasi peneliti. Untuk siswa yang bersikap manja, peneliti menemuinya pada observasi peneliti terkhusus pada kelas I, II, dan III yang merupakan kelas rendah, pada kegiatan pembelajaran. Pada beberapa kesempatan siswa merengek kepada guru dan mengadu ketika ada teman yang mengganggu mereka. Pengaruh teman dan lingkungannya terhadap perilaku siswa dapat terlihat pada saat pembelajaran pada kelas I-V, dimana ada beberapa siswa yang tenang, akan tetapi karena teman disebelahnya ramai, mereka juga menjadi ikut ramai. Untuk siswa yang mengalami keterlambatan belajar, terkhusus terlihat pada kelas $\mathrm{V}$, dimana terdapat 3 orang murid pindahan yang mengalami kesulitan 
saat pembelajaran sedang berlangsung. Pada saat pembelajaran, mereka hanya diam dan tidak melakukan aktivitas pembelajaran seperti teman yang lain. Untuk guru yang kesulitan untuk memilih nilai karakter yang sesuai dengan mata pelajaran, hal tersebut tidak sepenuhnya ditemui. Hal tersebut dikarenakan peneliti melihat pada RPP, guru sudah mencantumkan nilai karakter yang sesuai dengan KD mata pelajaran yang diajarkan, namun pada pelaksanaannya guru belum mengimplementasikan nilai karakter yang sudah dicantumkan dalam RPP tersebut dalam kegiatan pembelajaran secara optimal.

Berdasarkan hasil wawancara dengan kepala sekolah dan guru, dapat disimpulkan bahwa hambatan yang dialami guru dalam melaksanakan pendidikan karakter kepada siswa diantaranya:

a) Beberapa siswa yang bersikap manja, yang terlihat pada observasi kegiatan pembelajaran pada kelas I, II, dan III yang merupakan kelas rendah. Pada beberapa kesempatan siswa merengek kepada guru dan mengadu ketika ada teman yang mengganggu mereka.

b) Pengaruh teman dan lingkungan yang tidak baik terhadap perilaku siswa, dapat terlihat pada saat pembelajaran pada kelas $\mathrm{I}-\mathrm{V}$, dimana ada beberapa siswa yang tenang, akan tetapi karena teman disebelahnya ramai, siswa tersebut juga menjadi ikut ramai

c) Beberapa siswa yang agak terlambat belajar sehingga memerlukan waktu yang lama untuk menanamkan nilai keberanian, disiplin dan tanggung jawab. Terkhusus terlihat pada kelas $\mathrm{V}$, dimana terdapat 3 orang murid pindahan yang mengalami kesulitan saat pembelajaran sedang berlangsung. Pada saat pembelajaran, mereka hanya diam dan tidak melakukan aktivitas pembelajaran seperti teman yang lain

d) Guru belum dapat memilih nilai karakter yang sesuai dengan mata pelajaran dan terkadang belum dapat menjadi teladan atas nilai karakter yang dipilih. Pada dasarnya di dalam RPP, guru sudah dapat mencantumkan nilai karakter yang sesuai dengan KD mata pelajaran yang diajarkan, namun pada pelaksanaannya guru belum mengimplementasikan nilai karakter yang sudah 
dicantumkan dalam RPP tersebut dalam kegiatan pembelajaran secara optimal

\section{SIMPULAN}

Berdasarkan hasil penelitian dan pembahasan, maka penelitian ini dapat disimpulkan sebagai berikut:

a. Pelaksanaan Pendidikan Karakter di SD Negeri Joho 02 Sukoharjo terwujud dalam integrasi dalam program pengembangan diri, integrasi dalam kegiatan pembelajaran serta nilai karakter yang dikembangkan oleh sekolah. Integrasi dalam program pengembangan diri terdiri atas: a) Kegiatan Rutin yang terdiri atas kegiatan upacara, berdoa bersama sebelum dan sesudah pembelajaran, sholat berjamaah di masjid, serta piket kelas dan piket guru. b) Keteladanan yang terdiri atas berpakaian rapi, berbicara sopan, datang tepat waktu, disiplin, sholat berjamaah dan saling mengucap salam.c) Kegiatan spontan yang terdiri atas kegiatan menjenguk, melayat keluarga sekolah atau masyarakat sekitar sekolah, teguran guru, serta pujian guru kepada siswa. d) Pengkondisian yang terdiri dari guru saling mengisi kelas yang kosong, pemberian hukuman kepada siswa yang melanggar peraturan, kegiatan piket dan kebersihan sekolah, penyediaan tempat sampah dan pemajangan tata tertib sekolah. Integrasi dalam kegiatan pembelajaran terwujud dalam pencantuman nilai karakter di dalam RPP dan Silabus yang kemudian diimplementasikan dalam kegiatan pembelajaran. Nilai karakter yang dikembangkan di SD Negeri Joho 02 Sukoharjo yaitu nilai religius, jujur, disiplin, bersahabat/komunikatif, tanggung jawab, dan toleransi. 
b. Hambatan Pelaksanaan Pendidikan Karakter Di SD Negeri Joho 02 Sukoharjo antara lain: Beberapa siswa yang bersikap manja, pengaruh teman dan lingkungan yang tidak baik terhadap perilaku siswa, beberapa siswa yang agak terlambat belajar sehingga memerlukan waktu yang lama untuk menanamkan nilai keberanian, disiplin dan tanggung jawab, serta guru belum dapat memilih nilai karakter yang sesuai dengan mata pelajaran dan terkadang belum dapat menjadi teladan atas nilai karakter yang dipilih.

\section{DAFTAR PUSTAKA}

Ahmadi, Rulam. 2016. Pengantar Pendidikan: Asas dan Filsafat Pendidikan. Yogyakarta: Ar-Ruzz Media.

Alfajar, Lukman Hakim. 2014. Upaya Pengembangan Pendidikan Karakter Di Sekolah Dasar Negeri Sosrowijan. Skripsi. Yogyakarta: Universitas Negeri Yogyakarta.

Fadlillah, Muhammad dan Lilif Mualifatu Khorida. 2014. Pendidikan Karakter Anak Usia Dini: Konsep dan Aplikasinya dalam PAUD. Yogyakarta: ArRuzz Media.

Kelembagaan Ristekdikti. 2016. Undang-Undang Republik Indonesia Nomor 20 Tahun 2003 Tentang Sistem Pendidikan Nasional. https://www.google.co.id/url?q=http://kelembagaan. ristekdikti. go.id/wp-content/uploads/2016/08/UU_no_20_th_2003.pdf. (diakses 26 Januari 2017)

Kompri. 2016. Manajemen Pendidikan: Komponen-Komponen Kemajuan Sekolah. Yogyakarta:Ar-Ruzz Media.

Kurniawan, Syamsul. 2016. Pendidikan Karakter: Konsepsi dan Implementasi secara Terpadu di Lingkungan Keluarga, Sekolah, Perguruan Tinggi, dan Masyarakat. Yogyakarta: Ar-Ruzz Media.

Labib, Muhammad Zainul. 2014. Implementasi Pendidikan Karakter dan Pengaruhnya Terhadap Perilaku Akademik Siswa Kelas VI SD Negeri Jombang 1 Ciputat.. Skripsi. Jakarta: Universitas Islam Negeri Syarif Hidayatullah. 
Mu'in, Fachtul. 2016. Pendidikan Karakter: Konstruksi Teoritik dan Praktik. Yogyakarta: Ar-Ruzz Media.

Mulyaningsih, Irma. 2015. Implementasi Pendidikan Karakter pada Pembelajaran Tematik Di Kelas IV SD Prembulan Galur Kulon Ponorogo. Skripsi. Yogyakarta: Universitas Negeri Yogyakarta.

Subur. 2015. Pembelajaran Nilai Moral Berbasis Kisah. Yogyakarta: Kalimedia.

Suprihatiningrum, Jamil. 2016. Strategi Pembelajaran: Teori dan Aplikasi. Yogyakarta: Ar-Ruzz Media.

Sugiyono. 2014. Metode Penelitian Pendidikan (Pendekatan Kuantitatif, Kualitatif, dan R\&D). Bandung: Alfabeta 